\title{
TOWARDS AN EVIDENCE-BASED PROGRAM OF MENTORING IN THE ROMANIAN MILITARY
}

\author{
Marinel-Adi Mustață \\ "Carol I" National Defence University \\ Cătălin-Gabriel Predescu \\ "Carol I" National Defence University \\ Constantin-Laurențiu Anghel \\ "Carol I" National Defence University \\ Ionuț-Alexandru Radu \\ "Carol I" National Defence University \\ Diana Nicoară \\ "Carol I" National Defence University
}

\begin{abstract}
Mentoring seems to be beneficial for both employer and employee. However, success is not necessarily the outcome of a formal mentoring program. In this paper we look for the best evidence available that can support the formalization of mentorship in the Romanian Military. Where empirical data is not available we use case studies, historical data, and good practices. In the final section of the paper we formulate recommendations for the design of a semi-formal mentoring pilot program.
\end{abstract}

Keywords: mentor; mentee; mentoring program; military mentorship; evidence-based practice.

\section{INTRODUCTION}

Mentoring seems to be as old as human history. The Greek pantheon mentions Mentor and Telemachus, the Old Testament tells the story of Jethro and Moses, while Hinduism and Buddhism are traditions which have as cornerstone the guru - disciple interaction. In the Middle Ages the guilds composed of artisans or merchants institutionalized the notion of apprenticeship, while in modern times we have PhD advisers and coaches. In the military, mentorship is present from the time of the "knights and their squires to commanding Generals and their aides de champs" (Gleiman and Gleiman 2020).

Military history reveals many successful examples of mentor-mentee relationship. Two of the major figures of military history examples of mentee stand out as highly inspirational: Carl von Clausewitz and Dwight D. Eisenhower. Carl von Clausewitz met his mentor, General Gerhard von Scharnhorst, at the Prussian War College in 1801. During his time spent in this prestigious institution, Clausewitz gains Scharnhorst's respect and empathy. In the end, with the support of his mentor, from a student that had problems following lectures "because of his lack of essential knowledge" and was "close to despair", Clausewitz graduated first in his class (Billinger 2015). Clausewitz had the chance to work closely under Scharnhorst's command where he had to "write newspaper articles and analyses propagating the military reforms" and, in time, he became "Scharnhorst's closest and most devoted personal assistant". Later in his life, Clausewitz called Scharnhorst "father and friend of my spirit" (Billinger 2015). During this time Clausewitz developed his ideas about war, ideas that will be at the foundation of his life's masterpiece On War.

\footnotetext{
${ }^{1}$ Corresponding author: mustata.adi@unap.ro
} 
Dwight D. Eisenhower was introduced to his mentor, General Fox Conner, in 1920 by George S. Patton. At that time Fox Conner was looking for a young officer to work for him for three years as an executive officer while he was in command of the US 21st Infantry Brigade in Panama. Aware of the qualities of his subordinate and also being aware of Eisenhower's child death, Conner, "using the vast library in his quarters", began an intensive training program with his mentee with the purpose of turning lke "into a military history aficionado like himself" and to help him pass that tragic moment in his mentee's life (Cox 2010). Fox Conner had a great contribution in growing Eisenhower as a Supreme Commander, a coalition builder, using his vast experience and dedication in exposing his mentee to ideas ranging from Shakespeare to Nietzsche and from Matthew Steel's "American Campaigns" to Carl von Clausewitz "On War" (Cox 2010). On one occasion when Eisenhower was referring to Fox Conner, he mentioned that his mentor was "the ablest man I ever knew" (Cox 2010).

What these two examples of mentor-mentee have in common is that at one point both mentees were struggling to overcome their problems, Clausewitz in War College was unable to understand the lectures, and Eisenhower after the death of his child in 1921 was almost set towards failure in his career. But with the help of their extraordinary mentors, they overpass their weaknesses and problems to become their better version. With some certainty, it can be said that without their mentors today we would have talked about Eisenhower and Clausewitz differently or at all.

Beyond the historical argument, there is evidence that mentoring is an important development process for all parts involved, with major benefits for mentees, mentors, and organizations alike. From the mentee's perspective, connecting with a mentor at work is beneficial as it facilitates acculturation and career advancement. In this regard, in an article published in Harvard Business Review and entitled "CEOs Need Mentors Too", Suzanne de Janasz and Maury Peiperl (2015) state that mentoring programs help mentees "advance more quickly, earn higher salaries, and gain more satisfaction in their jobs and lives than people without mentors do". According to the same article, the mentoring relationship also has an impact on the organization: "the benefits are not only higher performance but also greater success in attracting, developing, and retaining talent" (de Janasz și Peiperl 2015). A mentoring relationship involves both career support and psychosocial support, the latter case involving a mentor's behavior that is geared toward developing "a sense of professional identity, self-efficacy, and self-worth" (Kram 1985).

\section{MENTORING IN THE MILITARY}

When searching for various mentoring programs already implemented in the military our main benchmark was the US Military and thus we follow Gleiman and Gleiman (2020) recent account of such programs. In the US Military there are two formal mentoring programs: MyVECTOR, for the US Airforce and Army Career Tracker (ACT) for the US Army. These programs provide web-based resources that allow access to career field, education and training information in addition to the option to be matched with a mentor. Despite this fact, the Navy and the Marine Corps have abandoned centralized, formal mentoring programs for being overly formal and started using less formalist and more decentralized guidance. We must also mention the fact that independent formal mentoring programs emerged outside the military, like eMentor and MilitaryMentors. These are run by non-profit organizations and their main purpose is to provide more adequate support to the members of the military than the official military mentorship programs.

Other mentorship programs that are worthy of mentioning are the Army Strategist Association (ASA) and PROMOTE. The former provides a program with guidance for both mentors and mentees that seek to foster mentorship and fellowship and strengthen the community of strategists. The later program was designed to develop mentorship and leadership for women working in Special Forces. When it comes to military mentorship programs, there is a real need of talking about In-House Programs. Despite the fact that the US Navy and Marine Corps have taken a decentralized approach when it comes to formal mentoring, they still have some programs in use, for example the Reverse Mentoring program. This program intends to cope with the biases and barriers of the senior Navy leaders, by pairing them junior Sailors, which basically become the mentors for their older colleagues. Both the mentors and the mentees gain valuable experience by learning the difficulties and the career 
progress of each other. Military mentorship programs target especially the military service members. Nevertheless, there are some programs that aim at the broader military community, particularly veterans and spouses. The main focus of these programs is assisting mentees in times of transition, in particular from military service to civilian workforce. A prime example in this case is the Veterati organization. They provide mentoring for military veterans, helping them accommodate more easily to the civilian life, the mentors being veterans themselves. Also, for the spouses there are many available programs, most notably, F.I.R.S.T Spouse Mentorship program ("Friendship, Information, Resiliency, Support and Trust"). This program is centered upon personal and professional development for military spouses, providing the chance to be part of a community of practice model and to foster life-long friendships. They also support active civic duty of each member and volunteerism.

Beside the American models, we were also able to find information about a particular mentorship program of the Israeli military, offered by The "Netzach Yehuda" association (also known as the "Haredi Nahal" organization). This program is unique, considering the fact that it is centered around combining Jewish faith with the military service, with the main goal of helping young ultraorthodox Jews to accommodate with the military life and still be able to remain connected to their religious practices and with their families back home (Nahal Haredi 2021).

While some of the authors of the paper have participated in or witnessed mentoring pilot programs in the Romanian Military educational system (M-A M \& C-L A), we were not able to identify a formal document institutionalizing such a program at the organizational level. In the Minister of Defence Order no.122/2014 concerning the annual evaluation of military personnel, modified and completed by the Minister Defence Order no. 230/2020, there are some mentions that could be considered mentoring with regards to the activities the immediate superior needs to perform in order to evaluate the subordinate: "the evaluation is continued throughout the evaluation period by means of monitoring, counseling and guidance of military personnel in fulfilling job descriptions and / or professional training". The Order 230 introduces the notion of additional counseling if professional objectives are not met and the possibility of modifying the initial objectives. In our interpretation this signals the possibility of things not working as planned and the effort of the legislator to find a solution within the legal framework available. Mentoring could thus help officers and noncommissioned officers better their professional performance and add some of the other possible advantages documented in the literature (e.g., job satisfaction, retaining talent etc.).

\section{WHAT IS THE BEST EVIDENCE ONE CAN RELY UPON WHEN DESIGNING A FORMAL MENTORING PROGRAM FOR THE MILITARY?}

Introducing a formal mentoring program in the Military may not necessarily be a success.

Long (1994) makes an extensive inventory of deficiencies a mentoring program may present:

- time consuming;

- poorly planned;

- poorly matched (e.g., value disagreement);

- poorly understood (e.g. misconceptions of roles);

- generating work tensions;

- lacking or overusing mentors;

- lacking access for women and minority groups;

- mentor's work style cloning (e.g., may copy leadership style and exclude the socially different);

- create poor relationships between mentor/mentee (e.g., overprotection);

- exaggerate visibility (e.g.,mentees' performance is excessively monitored due to the association with the mentor);

- imposing mentoring.

Faced with such concerns a decision-maker may want to reduce risks by using the best evidence available. This could be a challenging approach as more cues of an undergoing replication 
crises are starting to accumulate in fields of interest such as Psychology (Open Science Collaboration 2015).

However, there are also signs that subfields such as Behavioral Economics are thriving (Mustata and Bogzeanu 2017; Mustață and Ionașcu 2018). It seems that a careful scrutiny of the best evidence available can generate solid proof of efficiency. Therefore, we set out to find the best available evidence on military mentoring and mentoring in general. Our approach was to study the literature and in the gaps found to propose some recommendations based on case studies and good practices. The focus of the literature search was on evidence for mentoring and workplace mentoring in general, and military mentoring in particular.

Johnson and Anderson's (2010) literature review on military mentoring programs in the US "revealed not a single published evaluation of the efficacy of formal military mentoring", while a study in Taiwan with military students found participation in a formal mentoring program led to greater satisfaction, increased career commitment, and decreased stress. The same authors also mention a survey conducted in the US Army which revealed that officers are willing to join mentorship programs provided these are not formalized.

But most importantly for our purpose, Johnson and Anderson (2010) raise a new set of concerns and lingering questions regarding civilian and military mentoring programs:

- formal programs are usually using loose definitions of mentoring, which put participants in the position of not knowing what is expected from them;

- the perception of mentoring can sometimes be problematic as favoritism may be an implicit consequence of mentor-mentee interaction;

- mentoring programs will probably not be efficient if an all-size-fits-all approach is proposed. While all soldiers probably need mentoring, the most talented will have to be included in more intensive programs;

- mentoring can be perceived as a panacea for career advancement when in fact other factors such as motivation, intelligence, self-confidence or flexibility may play an important role in the process;

- developmental networks (e.g., short-term mentors, peer mentors, mentoring groups, online communities) may be a more robust solution one-on-one mentoring programs;

- not all mentoring is efficient. Dysfunctional mentoring can be worse than no mentoring;

intrinsic motivation seems to be more efficient than extrinsic motivation, however there is the problem of the challenge of cultivating the former in a formal environment;

- program oversight may help, but too much of it can undermine the goals of the mentoring program.

In a more recent article Johnson and Andersen (2015) conducted a survey with personnel attending the U.S. Naval War College and made an inventory of the following mentorship functions, from the mentee perspective: "advocate on my behalf", "developed my military skills", "enhanced my military career development", "offered me acceptance, support, and engagement", "provided direct training or instruction", "increased my self-esteem", "increased my visibility/exposure within the Navy", "enhanced my creativity and problem-solving skills", "developed my personal ethics and professional values", "provided emotional support/counseling", "assisted in establishing professional networks", "served to protect me", "provided me opportunities (choice assignments)", "help me bypass bureaucracy".

As the evidence regarding military mentorship was so scarce, we were forced to broaden our search in order to have some kind of solid bedrock for the recommendations we set out to formulate. This choice presented us with the following insights about important aspects of mentoring:

- mentor motivation - If the benefits of mentoring are obvious for the mentees, it is also important to investigate issues related to the decision to guide others. Allen, Poteet \& Burroughs (1997) highlight two overall psychological reasons why people mentor others: other-focused factors and self-focused factors. The first of these refers to the supportive behavior provided by mentors to help mentees succeed in the organization, the main reasons invoked by mentors being the desire to pass information on to others, the desire to build a competent workforce, the desire to help others 
succeed, the desire to help minorities/women move through organizational ranks, and so on. On the other hand, mentors agree to enter into a mentoring relationship because of the personal satisfaction they receive as a result of supporting others, the main intentions explaining the mentors' decision to mentor being gratification seeing others succeed/grow, personal desire to work with others, increase personal learning, pride desire to have influence in others, and so on.

- mentoring scope - Turner de Tormes Eby, et al. (2013) have shown that the following subfields of mentorship may emerge in youth, academic, and workplace interactions: instrumental support behaviors (i.e., task-related assistance, sponsorship, exposure and visibility, and coaching), psychosocial support behaviors (i.e., offering counseling, unconditional acceptance, encouragement, and role modeling), and relationship quality (i.e., overall perceptions of relationship quality, and liking).

- informal mentorships vs formal mentorships - Although workplace mentoring, which may include formal or informal relationships between individuals working in an organizational setting, has many positive effects, studies have assessed the relationship between formal and informal mentoring and career outcomes. Research shows that informal mentorships are more beneficial than formal mentorships: "Protégés of informal mentors viewed their mentors as more effective and received greater compensation than protégés of formal mentors." (Ragins and Cotton 1999) In the case of a formal mentoring relationship, in order to achieve the expected benefits, an aspect that must be considered involves making a match between the participants of the mentoring relationship, so that "formal mentoring relationships usually involve a third-party matching process and individuals may not even meet one another until after the match is made", given the importance of the similarity between mentor and mentee. Turner de Tormes Eby, et al. (2013)

- interpersonal relationship - Given that mentoring involves an interpersonal relationship, success is conditioned by certain key characteristics. In this regard, there is a lot of research that studies the characteristics of successful and failed mentoring relationships, emphasizing that the similarity between mentor and mentee is of particular importance, given the greater willingness of mentors to guide people like them, and creating a more rewarding and enjoyable relationship for all those involved in the process (Straus, et al. 2013). Thus, there is clear evidence that deep-level similarity, meaning similarity in values, beliefs or personality, is associated with greater psychosocial and career support and a higher quality of relationship: "The more similar the protégé views his or her mentor to be in terms of attitudes, values, beliefs, and personality, the stronger the identification process and the more likely that instrumental and psychosocial support will occur" (Turban, Dougherty and Lee 2002).

- age of mentee - The age of the mentee is an important factor to be considered in a mentorship program, as it can shorten or prolong the mentoring relationship, older mentees having more short-lived relationships with their mentors than their younger counterparts. Also, they receive less career-related mentoring, but still manage to experience higher levels of mutual learning and relationship quality, in both formal and informal mentoring programs (Finkelstein, Allen and Rhoton 2003).

\section{RECOMMENDATIONS FOR THE DESIGN OF A SEMI-FORMAL MENTORING PILOT PROGRAM IN THE ROMANIAN MILITARY}

After reviewing the best evidence available regarding military mentoring in particular, workplace mentoring and mentoring in general, we formulate the following recommendations for the design of a mentoring pilot program in the Romanian Military:

1. If the military organization relies exclusively on informal mentoring, then it is not difficult to infer that mentorships will be the exception rather than the rule. A powerful mechanism for leader development remains thus underappreciated and underused. Another possibility is that mentorship relations become more frequent but lack the strategic orientation towards organizational goals and most often are managed in an empirical fashion rather than evidence-based. Our recommendation is to formalize such a program, but make it as informal as possible. This entails that the military organization may still decide why and how the interaction takes place, but leave to the participants the who and when. A semi-formal version of a mentoring program could thus be designed. 
2. Due to the scarcity of evidence regarding military mentoring programs and the fact that we do not have any data from the Romanian Military, it is necessary that further steps be taken with maximum caution. Such a step would be a pilot program in which the design would be tested against a control group. Our recommendation is that the pilot program be tested as close as possible to a non-laboratory experimental setting.

3. Given that mentoring may come with certain possible negative connotations in the military it is necessary that prior to designing the program a survey is conducted in order to have a clear image of military staff perception.

4. The program should rely on a long-term strategy of leader development and propose clear and attainable goals for the participants. The scope of the program should entail career advancement but also psychological and instrumental support.

5. Given the differences between the category of forces (e.g. Land Forces vs Airforce) and even between specialties (e.g., infantry vs logistics) it is highly unlikely that a one-size-fits-all approach be successful. In contrast, a rather decentralized approach should be able to take into account all the particularities of different units.

6. Not everyone is suited to be a mentor and not everyone wants to be mentored, therefore participation in the program should not be compulsory and inclusion criteria should be rather high for the mentors. These criteria could consist of interpersonal skills, career achievements and intrinsic motivation.

7. The mentor-mentee relationship should be established between the two parties based on shared values and common interests. A possible solution to identify these shared values and common interests and purposes of the participants in the mentoring relationship could be to provide the opportunity to socialize prior to the start of mentoring programs. By calling on certain matchmakers, i.e., some consultants external to the organization, to act as intermediaries, a correct match can be made between mentor and mentor depending on their personality. Performing personality tests to ensure compatible matches between mentor and mentor should be an important part of matchmaking.

8. Developmental mentorships should also be available, in the sense that the mentee should have several possible routes of getting the needed support, including other mentors and online resources.

9. Both mentors and mentees should not be burden with even more formalities to deal with. The paperwork required should be minimum and the agenda of meetings should be left on the participants' decision.

\section{REFERENCES}

Allen, Tammy D., Mark L. Poteet, and Susan M. Burroughs. 1997. "The Mentor's Perspective: A Qualitative Inquiry and Future Research Agenda." Journal of Vocational Behavior 51 (1): 70-89.

Billinger, Vanya Eftimova. 2015. The woman behind the making of On War. Oxford University Press.

Cox, Edward. 2010. Grey Eminence: Fox Conner and the art of mentorship. New Forums Press.

de Janasz, Suzanne, and Maury Peiperl. 2015. "CEOs Need Mentors Too". Harvard Business Review Home, April. Accessed March 7, 2021. https://hbr.org/2015/04/ceos-need-mentors-too

Finkelstein, Lisa M., Tammy D. Allen, and Laura A. Rhoton. 2003. "An Examination of the Role of Age in Mentoring Relationships". Group and Organizational Management 28 (2): 249-281.

Gleiman, Ashley, and Jan K. Gleiman. 2020. "Mentoring in the Military". New Directions for Adult and Continuing Education 59-69.

Johnson, Brad W., and Gene R. Andersen. 2015. "Mentoring in the U.S. Navy: Experiences and Attitudes of Senior Navy Personnel". Naval War College Review 68 (3): 76-90.

Johnson, Brad W., and Gene R. Anderson. 2010. "Formal mentoring in the U.S. Military - Research Evidence, Lingering Questions, and Recommendations". Naval War College Review 1-14. 
Kram, Katy E. 1985. Mentoring at Work: Developmental Relationships in Organizational Life. Glenview, III: Scott Foresman.

Mustata, Adi, and Cristina Bogzeanu. 2017. Programul euristicilor și biasurilor. Aplicații și implicații în domeniul militar. București: Editura Unversității Naționale de Apărare "Carol I".

Mustață, Marinel-Adi. 2020. "Intuitive Decision-Making in the Military". Proceedings of the 16th International Scientific Conference - Strategies XXI. Bucharest: "Carol I" National Defence University Publishing House: 89-94.

Mustață, Marinel-Adi, and Alina Ionașcu. 2018. "The Story of Behavioral Economics - In a Nutshell." Proceedings of the 14th International Scientific Conference Strategies XXI (Volume 3). Bucharest. 204-212.

Nahal Haredi. 2021. Veterans Website. Accessed March 7, 2021. https://nahalharedi.org/

Open Science Collaboration. 2015. "Estimating the reproducibility of psychological science." Science.

Ragins, B.R. , and J.L. Cotton. 1999. "Mentor functions and outcomes: a comparison of men and women in formal and informal mentoring relationships". The Journal of applied psychology 84 (4): 529-550.

Straus, S. E., M. O. Johnson, C. Marquez, and M. D. Feldman. 2013. "Characteristics of successful and failed mentoring relationships: a qualitative study across two academic health centers". Acad Med 88 (1): 82-89.

Thaler, Richard H, and Cass R. Sunstein. 2009. Nudge: improving decisions about health, wealth, and happiness. New York: Penguin Books.

Turban, D. B., T. W. Dougherty, and F. K. Lee. 2002. "Gender, race, and perceived similarity effects in developmental relationships: The moderating role of relationship duration". Journal of Vocational Behavior 61 (2): 240-262.

Turner de Tormes Eby, Lillian, Tammy D. Allen, Brian J. Hoffman, Lisa E. Baranik, Julia B. Sauer, Sean Baldwin, and Ashley Morrison. 2013. "An interdisciplinary meta-analysis of the potential antecedents, correlates, and consequences of protégé perceptions of mentoring". Psychological Bulletin 139 (2). 